\title{
DESCRIPTION OF THE EGG OF Anopheles (Anopheles) intermedius (PERYASSU, 1908) (DIPTERA: CULICIDAE) BY SCANNING ELECTRON MICROSCOPY.
}

Oswaldo Paulo FORATTINI, Maria Anice Mureb SALLUM \& Daniel C. FLORES

\begin{abstract}
SUMMARY
The egg of Anopheles (Anopheles) intermedius (Peryassu, 1908) is described and illustrated with scanning electron micrographs. Literature data on An. (Ano.) maculipes (Theobald, 1903) is provided.
\end{abstract}

KEYWORDS: Anopheles intermedius; Diptera; Culicidae; Egg morphology

\section{INTRODUCTION}

Since its description, Anopheles (Anopheles) intermedius (Peryassu, 1908) has been the subject of several taxonomic studies. The immature stages of this species are not adequately described and the egg is incompletely known. Although the morphology of the egg was not studied in great depth, descriptions illustrated with drawings and microphotographs at stereomicroscopic level remain the only found in the literature (COSTA LIMA, 1929; CAUSEY et al., 1944; FLOCH \& ABONNENC, 1951). Except for An. peryassui Dyar \& Knab (LINLEY \& LOUNIBOS, 1994) and An. mattogrossensis Lutz \& Neiva (LINLEY \& MILSTREY, 1995) the eggs of other neotropical species of the Anopheles subgenus are not adequately described. Here we provide, for the first time, the description of the egg of An. intermedius illustrated with scanning electron micrographs.

\section{MATERIAL AND METHODS}

Eggs were obtained by oviposition from 5 females collected in Shannon trap in Galiléia Farm, Pariquera-Açu county, southern São Paulo, Brazil. The females were fed and left to lay eggs in small glass vials with wet cotton and filter paper on the bottom. Once they had oviposited, the eggs were allowed to embryonate for 24 hours and they were fixed in alcoholic Bouin's solution. Fixed eggs were prepared for scanning electron microscopy following methodology described by FORATTINI \& MARUCCI
(1993). The eggs were examined in a JEOL JSM-P15 scanning electron microscope after sputter-coating with carbon/gold. Measurements were made in a stereomicroscope using a digital length-measuring set WILD MMS 235. Widths were measured in the circumferential direction, and lengths in the long axis of the eggs. Terminology follows HARBACH \& KNIGHT (1980). The scanning electron micrographs were taken by the authors.

\section{RESULTS}

Size: Width $135-161 \mu \mathrm{m}$ (mean $146 \pm 0.01 \mu \mathrm{m}$ ), length 610 $669 \mu \mathrm{m}$ (mean $639 \pm 0.02 \mu \mathrm{m}$ ), length/width ratio $3.90-4.80$ (mean $4.37 \pm 0.16)$ ( $n=34$ eggs from 4 females). Color: black. Overall appearance: egg broadly boat-shaped in ventral view (Fig. 1A,B), the contour is elongate and somewhat fusiform, widest at about 0.3 from anterior end, then gradually tapered to both extremities. In lateral view, ventral surface nearly straight, dorsal surface convex with both extremities curved upward in ventral direction. Deck elongate, narrow (Fig. 1 A,B); float long and thin, lateral in position (Fig. 1C); frill well distinct, disposed along both sides of deck as a rather distinct palisade (Fig. 1C,D). Ventral surface: deck continuous, narrow, uniform in size, extending from anterior to posterior extremities and completely enclosed by frills (Fig. 1A,B). Frill continuous, well developed, shallow along anterior and posterior ends (Figs. 2E;3C), deeper along deck region (Fig. 1A-C). Outer chorion disposed in a system of

Supported by grants n ${ }^{\circ} 95 / 7157-2$ and 95/0381-4, Fundação de Amparo à Pesquisa do Estado de São Paulo.

Departamento de Epidemiologia, Núcleo de Pesquisa Taxonômica e Sistemática em Entomologia Médica (NUPTEM), Faculdade de Saúde Pública, Universidade de São

Paulo, Av. Dr. Arnaldo 715, 01246-904 São Paulo, SP. Brasil

Correspondence to: Prof. Oswaldo Paulo Forattini. FAX: 55-011-2821898, email: opforati@spider:usp.br 
FORATTINI, O.P.; SALLUM, M.A.M. \& FLORES, D.C. - Description of the egg of Anopheles (Anopheles) intermedius (Peryassu. 1908) (Diptera: Culicidae) hy seanning electron microscopy. Rev. Inst. Med. trop. S. Paulo, 39(1): 5-9, 1997.
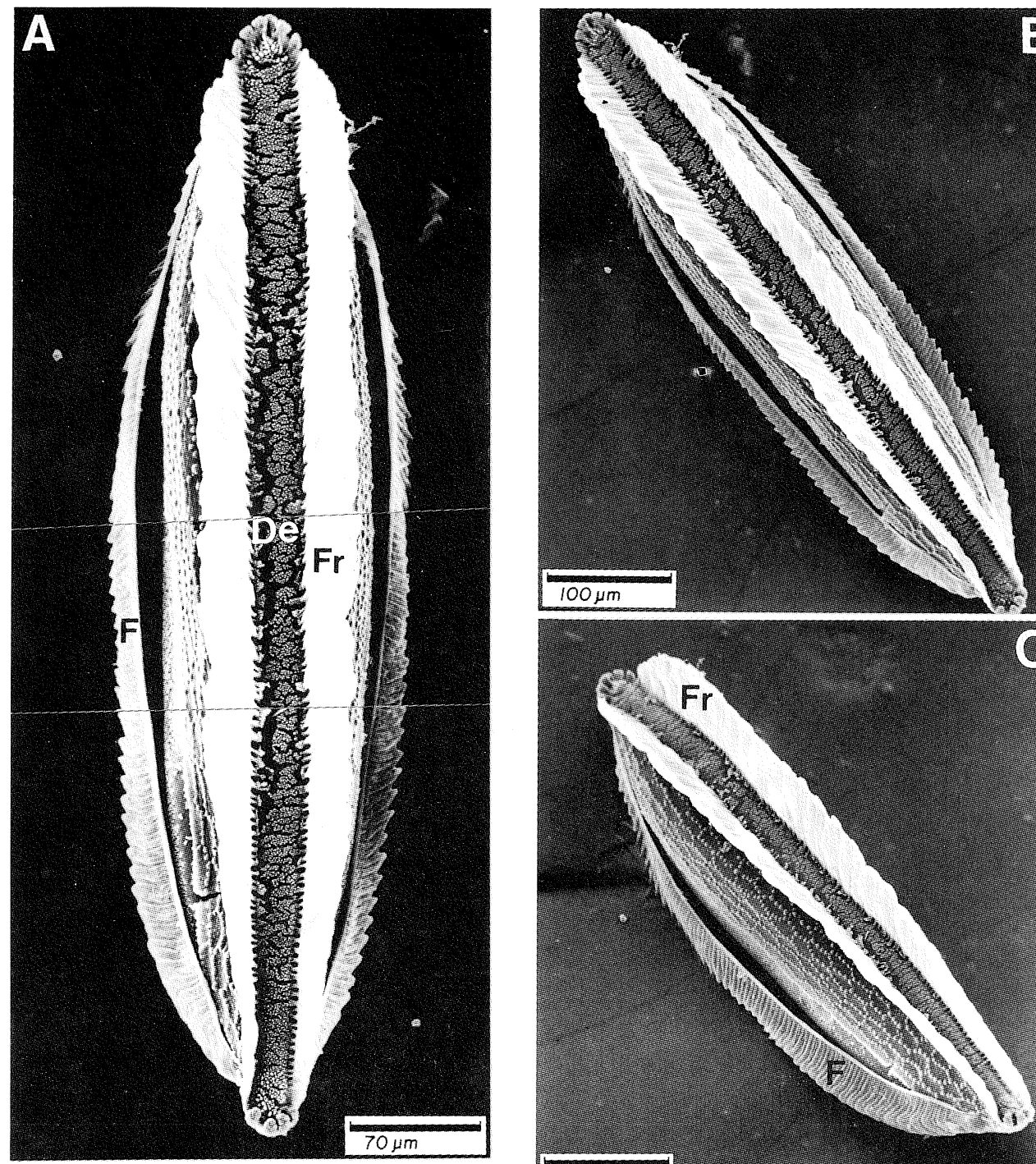

B


Fig. 1. Anopheles (Ano.)

intermedius. A,B, Entire egg. overall view ventral surface, anterior end at top; C, Entire egg, ventrolateral view, showing frill and float; D. Detail of anterior end, showing frill and lobed tubercles; E. Detail of mid region of deck.

Fig.1-3. Abbreviations used: De deck; F - float; Fr - frill; LoT - lobed tubercles; Mi - micropyle; MiC micropylar collar. 
FORATTINI, O.P.; SALLUM, M.A.M. \& FLORES, D.C. - Description of the egg of Anopheles (Anopheles) intermedius (Peryassu, 1908) (Diptera: Culicidae) by scanning electron microscopy. Rev. Inst. Med. trop. S. Paulo, 39(1): 5-9, 1997

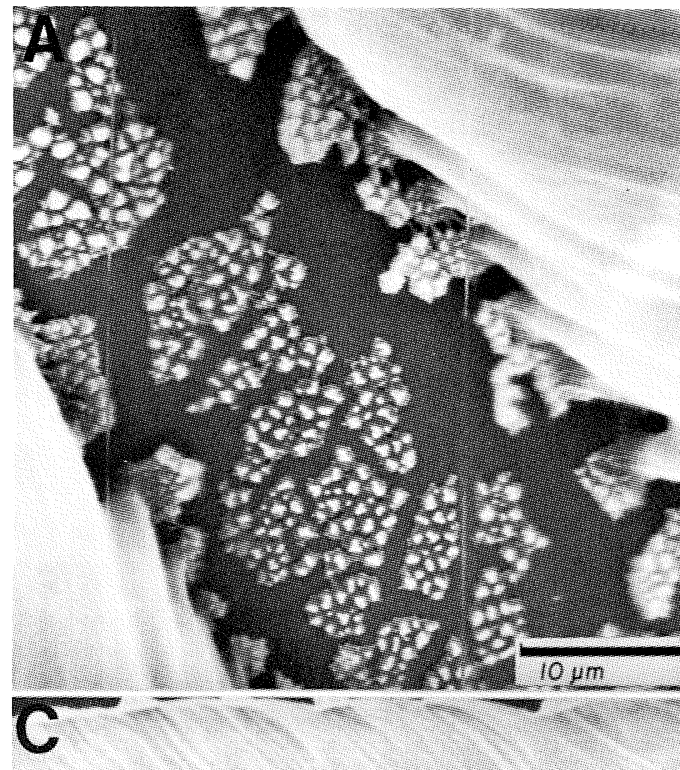

$\mathrm{Fr}$

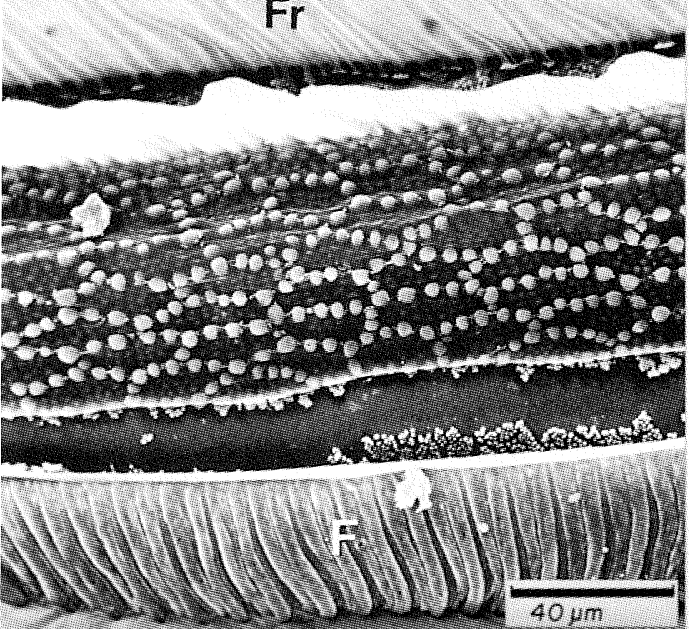

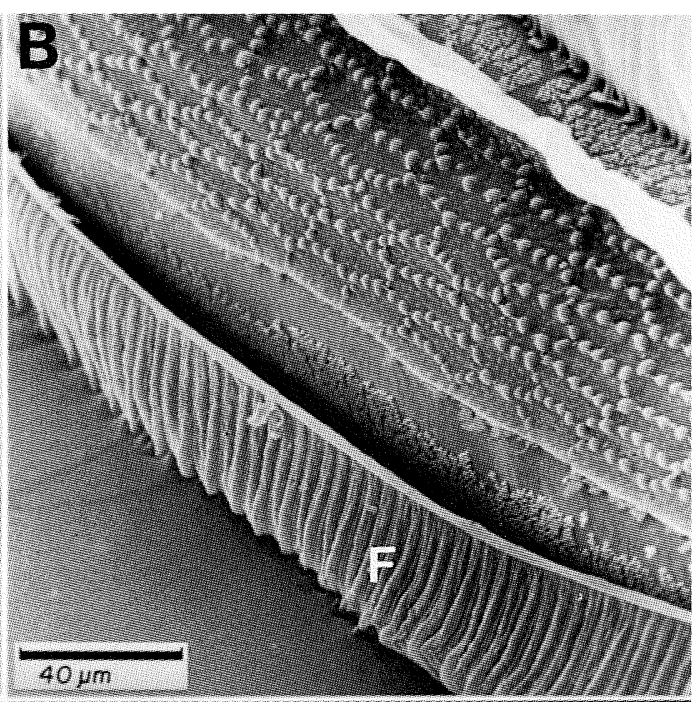
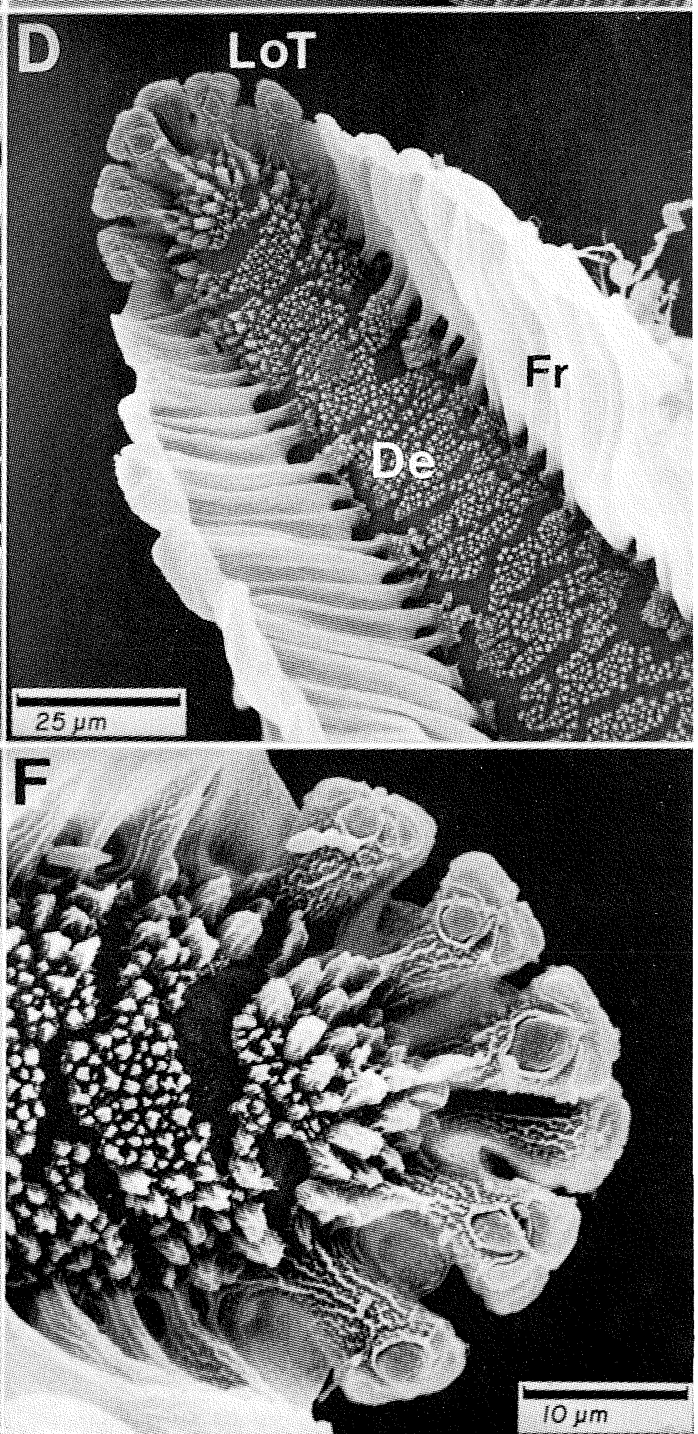

Fig. 2. Anopheles (Ano.)

intermedius. A, Detail of mid region of deck; B.C. Detail of lateral region and float; D. Anterior end, ventral surface; E.F. Lobed tubercles, anterio 
FORATTINI. O.P.: SALLUM, M.A.M. \& FLORES, D.C. - Description of the egg of Anopheles (Anopheles) intermedius (Peryassu. 1908) (Diptera: Culicidae) by scimning electron microscopy. Rev. Inst. Med. trop. S. Paulo, 39(1): 5-9, 1997.
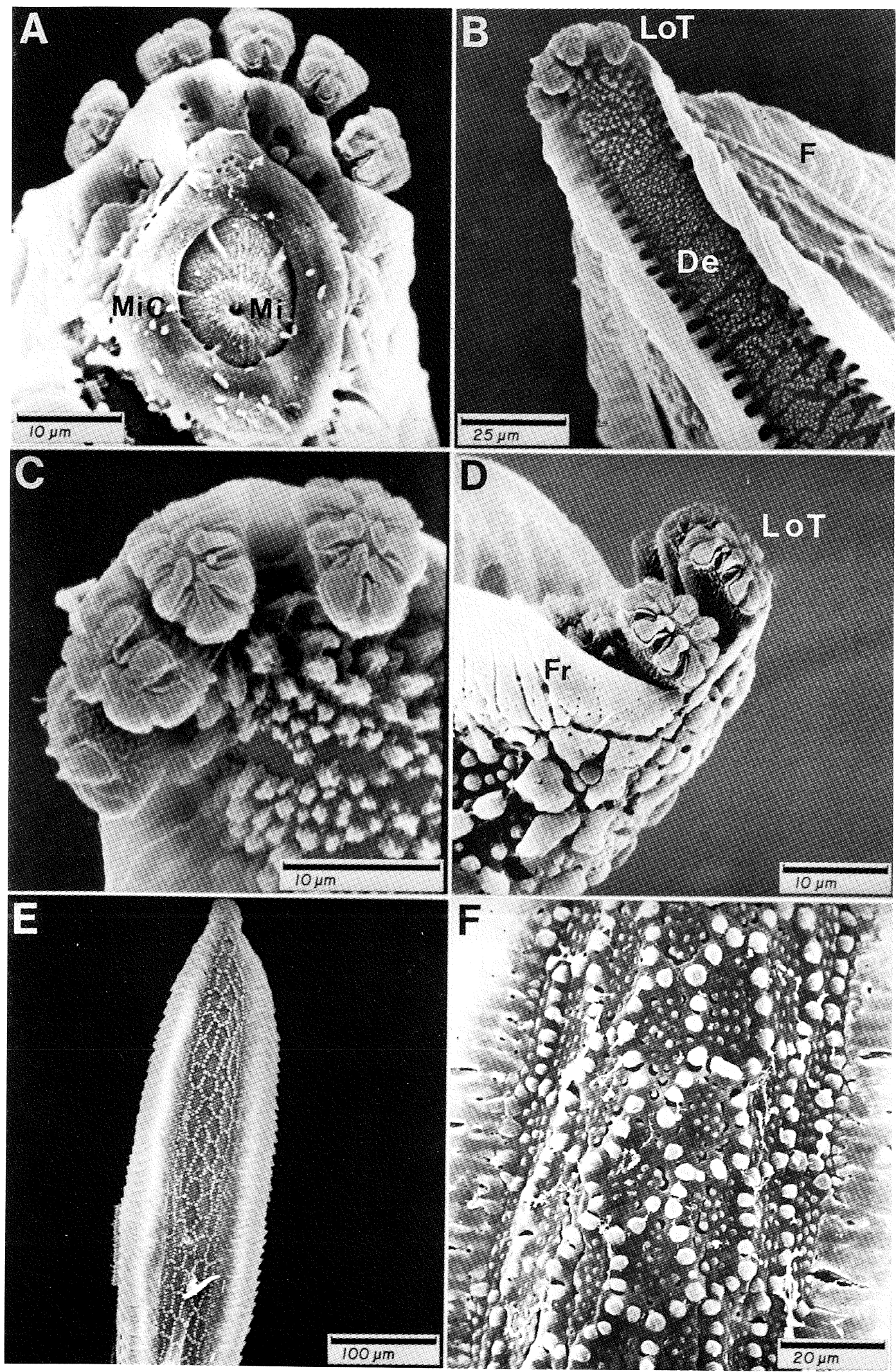

Fig. 3. Anopheles (Ano.) intermedius. A

Micropylar apparatus; B Posterior end, ventral surface; C, Lobed tubercles, posterior end: D, Lobed tubercles, posterior end. lateral view; E, Entire egg, dorsal view: F. Detail of dorsal surface, 
FORATTINI. O.P.: SALLUM. M.A.M. \& FLORES, D.C. - Description of the egg of Anopheles (Anopheles) intermedius (Peryalssu, 1908) (Diptera: Culicidae) by scanning electron microscopy. Rev. Inst. Med. trop. S. Paulo, 39(1): 5-9, 1997.

small tubercles uniformly distributed over entire deck (Fig. 1E), tubercles similar in middle deck region (Fig. 2A), larger in anterior (Fig. 2E,F) and posterior regions (Fig. 3C). Anterior and posterior ends of deck bearing a row of 5-7 lobed tubercles (Figs. 2D-F;3C). Lobes surrounded by tubercles that are larger than those on remainder of deck. Lobes well separated from each other, structurally similar to fingerlike projections that radiate outwards from the centre and disposed at swollen end of a peduncular projection (Figs. 2D,E;3D). Dorsal and lateral surfaces: plastron on lateral surface confined to narrow stripes disposed on both sides between the float and frill (Fig. 1C), detailed structure of lateral plastron cells similar to that on dorsal surface (Fig. $2 \mathrm{~B}, \mathrm{C})$, but underneath the float similar to that on deck surface (Figs. 1E;2B); outer chorionic cells of dorsal surface usually hexagonal or pentagonal in shape, each longer than wide, interior of each cell consists of a surface that is perforated by small pores and with small rounded tubercles (Fig. 3E,F). Outer chorionic reticulum bounding each cell consists of an indistinct palisade of usually rounded tubercles. Float large, extending along entire length of lateral surface of egg, ribs about 42 in number (Fig. 1C). Anterior end, micropyle: anterior end slightly wide than posterior end, rounded. Micropylar collar separated from anterior margin of frill. Collar surface smooth, outer margin of collar somewhat round in shape, inner boundary with thin ridges extending radially towards micropyle (Fig. $3 \mathrm{~A}$ ). Deck surface finely striated, micropylar orifice situated near center of a low mound (Fig. 3A). Posterior end: similar to anterior end with respect to frill and conformation of plastron and deck. Tubercles slightly different from those of anterior end in overall appearance (Fig. 3C.D).

\section{DISCUSSION}

Egg of An. intermedius was previously described and illustrated by COSTA LIMA (1929). Based on Peryassu's (1908) drawing of An. maculipes, COSTA LIMA (1929) called attention to the fact that the egg of this species is similar to that of An. maculipes. Posteriorly, CAUSEY et al. (1944), studying the eggs of An. intermedius and An. maculipes at stereomicroscopic level, distinguished them by features of the frills. In An. intermedius the frill is oblique to the long axis of the egg but perpendicular in An. maculipes. Furthermore, CAUSEY et al. (1944) illustrated morphological variations they found in the frill of the egg of An. intermedius, the frill was discontinuous in some individuals of An. intermedius, becoming small circles on that part where it is discontinuous.

Although similar to An. maculipes, the egg of An. intermedius can be easily recognized by features of frill, float and lobed tubercles as given in the description. However, it will be necessary to study the morphology of the egg of other species of the Anopheles subgenus, with scanning electron microscopy, to establish difference and comparison among the species.

\section{RESUMO}

\section{Descrição do ovo de Anopheles (Anopheles) intermedius (Peryassu, 1908) (Diptera: Culicidae) por microscopia de varredura}

Os ovos de An. intermedius foram descritos e ilustrados por COSTA LIMA (1929). Este autor, baseando-se nos desenhos de Peryassu (1908) para An. maculipes, chamou atenção para o fato do ovo desta espécie ser semelhante ao de An. maculipes. Posteriormente, CAUSEY et al. (1944), estudando os ovos de An. intermedius e An. maculipes ao estereomicroscópio, diferenciou-os por caracteres da franja. Em An. intermedius a franja é oblíqua ao eixo longitudinal do ovo, mas perpendicular em An. maculipes. CAUSEY et al. (1944) ilustraram as variações morfológicas que encontraram na franja do ovo de An. intermledius. Os autores observaram que a franja apresentava-se descontínua em alguns espécimens de An. intermedius. tornandose em pequenos círculos nessa região.

Embora semelhante ao de An. maculipes, os ovos de An. intermedius podem ser facilmente reconhecidos por características da franja, flutuadores e tubérculos lobados, como pode ser observado na descrição. Contudo, será necessário estudar a morfologia dos ovos de outras espécies do subgênero para que se possa estabelecer as diferenças e fazer comparações precisas entre as espécies.

\section{ACKNOWLEDGMENTS}

To Rosemeire P. Domingues for typing the manuscript.

\section{REFERENCE}

1. CAUSEY. O.R.: DEANE. L.M. \& DEANE. M.P. - An illustrated key to the eags of thirty species of Brazilian anophelines, with several new descriptions. Amer J. Hyg., 39: 1-7, 1944

2. COSTA LIMA. A. dia. - Sobre alguns anophelineos encontrados no Brasil Mem. Inst. Oswaldo Cruz, 12(suppl.): 275-293, 1929

3. FlOCH, H. \& ABONNENC. E. - Anophèles de la Guyane Française. Arch. Inst. Pasteur Guyane franç., (236): 1-91. 1951

4. FORATTINI, O.P. \& MARUCCI. D. - Scanning electron microscopy of the exts of two species of Anopheles (Kerteszia) (Diptera: Culicidae). Mem. Inst Oswaldo Cruz, 88: 349-352. 1993

5. HARBACH, R.E. \& KNIGHT. K.L. - Taxonomists' glossary of mosquito anatomy. Marlton N.J, Plexus Pub., 1980.

6. LINLEY, J.R. \& LOUNIBOS, L.P. - The remarkable egg of Anopheles perasail (Diptera: Culicidae). Mosq. Syst., 26: 25-34. 1994

7. LiNLEY. J.R. \& MILSTREY. E.G. - The eggs of Anopheles (Anopheles) mattogrossensis and Chagasia fajardi (Diptera: Culicidae). Mos(f. Syst.. 27 $27-39.1995$

8. PERYASSÚ, A.G. - Os Culicideos do Brazil. Rio de Janeiro, Typ. Leuzinger. 1908.

Recebido para publicação em (04/11/1996

Aceito para publicação em 17/01/1997 
